\title{
Assessment of Nutrient Concentration in Sokori River, Southwest Nigeria
}

\section{*11ERUOLA, AO; OJEKUNLE, ZO; AMORI, AA; AWOMESO, JA; AMOLE OE; ANTHONY, DE}

\author{
${ }^{I}$ Department of Chemical Sciences, Yaba College of Technology, Lagos, Nigeria \\ ${ }^{2}$ Department of Environmental Resources Management and Toxicology, University of Agriculture, Abeokuta, Nigeria \\ ${ }^{3}$ Department of Water Resources Management and Agrometeorology, University of Agriculture, Abeokuta, Nigeria \\ *1:layosky@yahoo.com,a2: oojekunle@yahoo.com,b3:drdeolaamori@gmail.com,c3:Julius_awomeso@yahoo.com, \\ d3:deanthony@yahoo.com,e3:amoleoluyinka2013@gmail.com,
}

KEYWORDS: Nutrients, Sokori stream, Phosphate, Nitrate, Sulphate, Runoff

\begin{abstract}
Water management planners are facing considerable uncertainties on future demand and availability of water partly due to concentration of nutrient leading to excessive unsightly growth of aquatic plants and algal bloom in rivers. This study was carried out to assess the trend of nutrient concentration in Sokori stream in Southwest Nigeria. The selected nutrients determined in the stream were nitrate, sulphate and phosphate, dissolved oxygen and biological oxygen demand. Water samples from 10 sampling point at $100 \mathrm{~m}$ interval were examined to assess the variation in concentration of nutrients along the stream using standard method. Descriptive statistics was used in data analysis. The result showed that high nutrient concentrations were established at the middle section of the stream. It is obvious that sulphate has the highest concentration $(3.60 \mathrm{Mg} / \mathrm{l})$, followed by phosphate $(2.13 \mathrm{Mg} / \mathrm{l})$ then nitrate $(0.89 \mathrm{Mg} / \mathrm{l})$. However, the nutrient concentrations in the stream were below the acceptable limit set by the World Health Organization. Furthermore, it was observed that where the nutrients concentration $\left(\mathrm{PO}_{4}=5.16 \mathrm{Mg} / \mathrm{l}, \mathrm{SO}_{4}=9.78 \mathrm{Mg} / \mathrm{l}, \mathrm{NO}_{2}=1.46 \mathrm{Mg} / \mathrm{l}\right)$ and the $\mathrm{BOD}_{5}$ $(10.24 \mathrm{Mg} / \mathrm{l})$ were highest at the mid - section of stream, while the DO concentration (3.63 $\mathrm{Mg} / \mathrm{l}$ ) lowest indicating concentrated aquatic life (macro and micro-organisms) activity. Nutrient enrichment leads to excessive growth of primary producers as well as heterotrophic bacteria and fungi, which increases the metabolic activities of stream water leading to a depletion of dissolved oxygen. The low discharge of stream and its fairly flat terrain nature also influenced the metabolic activities in the mid- section of the stream although there was no evidence of accumulation of nutrient leading to eutrophication risk. (C) JASEM
\end{abstract}

http://dx.doi.org/10.4314/jasem/v19i3.14

\section{Introduction}

Although nutrients are essential for maintenance of healthy aquatic life, it's high concentrations in water body will lead to excessive unsightly growth of aquatic plants leading to algal bloom in the river which eventually leads to a dozen adverse effects on the river including reduction in dissolved oxygen required for macro invertebrates, fishes and microorganisms, shortening of life span of the river or lake itself (Mallin et al., 2006). The river or lake then loses its aesthetic value that are economically and ecologically important, as well as its productivity as a result of the death of aquatic life and ultimately will not provide use for human activities. Nutrient concentrations in streams and rivers have been strongly correlated with human land use and disturbance gradients (Howarth et al. 1988) and human population density (Cook and Kelly, 1992; Howarth et al., 1988). Nutrient enrichment of aquatic systems from anthropogenic sources includes point and nonpoint sources. Both have degraded aquatic systems. Point sources of nutrients include wastewater effluent (both municipal and industrial) and storm sewer discharge. In contrast to point sources of nutrients that are relatively easy to monitor and regulate, nonpoint sources such as livestock, crop fertilizers, and urban runoff exhibit more spatial and temporal variability. Following strong regulation of point source inputs in response to the Clean Water Act, nutrients from nonpoint sources are now the major source of water pollution worldwide (Capone and Kiene, 1988). Increasing imperviousness, increased runoff from urbanized surfaces, and increased municipal and industrial discharges all result in increased loadings of nutrients to urban streams. This makes urbanization second only to agriculture as the major cause of stream impairment, even though the total area covered by urban land in the Nigeria is minor compared to agricultural area. Nitrogen fertilization is the main source of Nitrogen in streams and rivers (Gatseva et al. 2008b). Similarly, urbanization generally leads to higher phosphorus concentrations in urban catchments (Paul, 1998). The Sokori stream area is characterized by different land use including a market, cattle ranch residential area, various unethical dumping sites among others. Downstream of the Sokori stream is also associated with domestic activities like washing, 
bathing and other human-related activities, hence its vulnerability to flux of nutrients. This study therefore intends to examine the transport and retention of nutrients in the stream reaches.

Description of Study Area: Sokori stream (7 $9^{\prime} 39^{\prime \prime} \mathrm{N}$, $\left.3^{\circ} 20^{\prime} 54^{\prime \prime} \mathrm{E}\right)$ is found in Abeokuta, Ogun State, southwest Nigeria. it covers an areal extent of 46.33 $\mathrm{km}^{2}$. The Sokori stream is adjoined by Kuto market and a series of fast growing communities located within the metropolis. The area is characterized by a tropical climate with distinct wet and dry seasons with bimodal rainfall pattern and mean annual air temperature of about $30^{\circ} \mathrm{C}$. The annual rainfall ranges between 1200 and $1400 \mathrm{~mm}$. According to "Gbadegesin and Olabode, (1999), the soils of the Abeokuta metropolis belong to the major soil group of ferruginous tropical soils and can be further classified into four soil associations. All the four soil associations can be used for producing food crops such as cassava, maize can also be profitably used for producing tree crops such as cocoa and kola.

The inhabitant's livelihood strategies include agriculture, short and long-distance trading, and a variety of urban occupations. Traditionally, very little farming is carried out within the limits of Abeokuta while the belt surrounding the town was used for cultivation of crops. The town land was used primarily for residential and public buildings, markets, shrine and paths. Only a small portion of the city land is used for production of vegetable. However, there are lots of pre-urban area within Abeokuta were farming is largely the inhabitants occupation. Crops such as yam, maize, cassava, cocoyam, Mellon, okra, tomato, pepper and vegetables are the major crops grown in the area. Farming in this region is almost entirely reliant on 6 to 7 months of rainfall and augmented by small scale irrigation in particular for vegetables.

\section{MATERIALS AND METHODS}

The river and the surrounding communities were visited in December, 2013 during the dry season. The objective of the visit was to make a preliminary assessment of the extent of possible damage of the upstream discharge in the communities might have on stream.

Study location layout: The sampling points in the study area are shown in Figure 1 The stream is located at a densely populated area which contributes immensely to its pollution. The water from the upstream appeared colourless, while the water discharged in the middle was slightly dull in colour. The upper stream flows slowly, but towards the middle to the downstream, the water flow rapidly indicates constant discharge from the community activities. The extent of assessment was about $1 \mathrm{~km}$ along the downstream area.

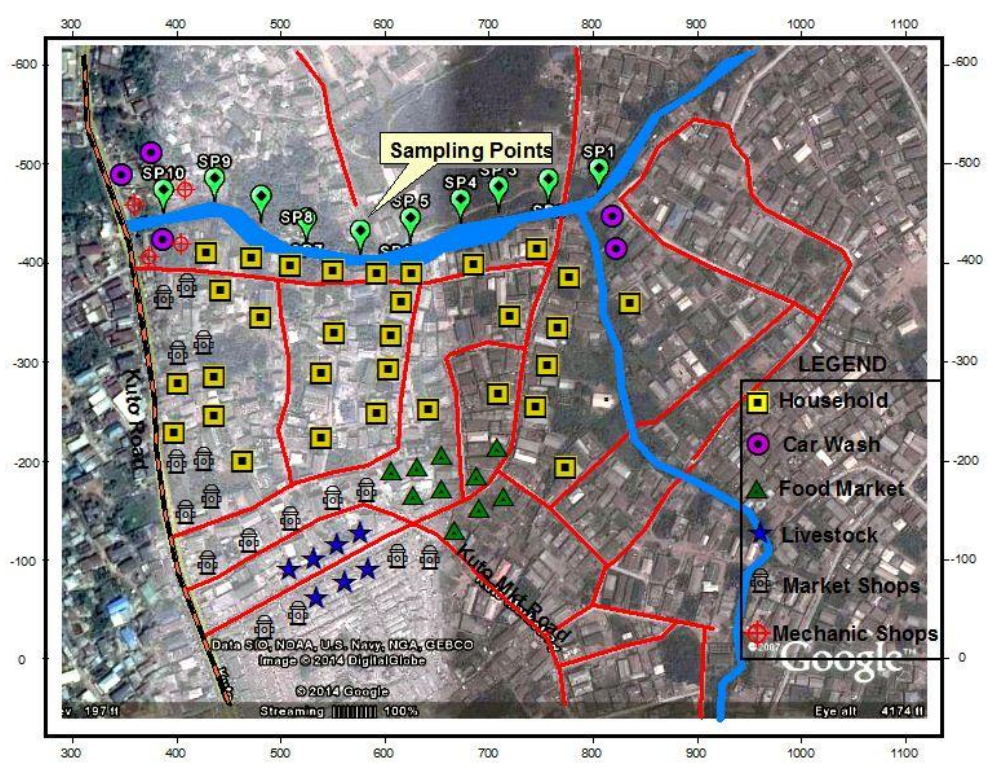

Fig 1: The locations Map showing sampling points at 100m interval and land use pattern along Sokori Stream

\section{SOURCE: GOOGLE EARTH, 2014.}

Water Sampling: Water samples from the Sokori stream were taken along the water stretch, marked "SP1- SP10". Sampling interval was $100 \mathrm{~m}$ from upstream end. The sample locations are as shown in figure 1. At each $100 \mathrm{~m}$ interval the co-ordinates of that sampling point was taken using a Global Positioning System device.

Nutrient Assessment Criteria: The following categories were used to describe nutrient trends in the stream water quality: Sulphate; Nitrate, Phosphate, 
Biological Oxygen Demand (BOD 5 ), Dissolved Oxygen

\section{RESULTS AND DISCUSSION}

Nutrient Concentration in Sokori Stream: Figure 2 shows the concentration of nutrients along the Sokori stream reach. It was observed that nutrient concentration in stream was highest in the midsection of the stream. This is as a result of highly polluted runoff inputs from the densely concentration of activities around the stream at the middle section. The point source of nutrients majorly entering the stream at the mid-section mostly comes from household sewage system and other domestic activities. The non-point source of nutrients in the stream is the Kuto market which is located at a higher elevation of the stream, hence, gravity movement of waste water from the market (abattoir and animal ranch) drains into the river. The excreta from the animals and blood contribute majorly to the dissolved nitrogen concentration in the stream. The Sokori stream also drains the $1 \mathrm{~km}$ Kuto road along which are mechanic garages and lot of generator usages that contributes sulphate $\left(\mathrm{SO}_{4}\right)$ to the stream through surface run-off. Furthermore, it was observed that where the nutrients concentration $\left(\mathrm{PO}_{4}=5.16 \mathrm{Mg} / 1\right.$, $\left.\mathrm{SO}_{4}=9.78 \mathrm{Mg} / \mathrm{l}, \quad \mathrm{NO}_{2}=1.46 \mathrm{Mg} / \mathrm{l}\right)$ and the $\mathrm{BOD}_{5}$ $(10.24 \mathrm{Mg} / \mathrm{l})$ were highest at the mid - section of stream, the DO concentration $(3.63 \mathrm{Mg} / \mathrm{l})$ was lowest indicating concentrated aquatic life (macro and micro-organisms) activity. Nutrient enrichment leads to excessive growth of primary producers as well as heterotrophic bacteria and fungi, which increases the metabolic activities of stream water and may lead to a depletion of dissolved oxygen (Mallin et al. 2006). The low discharge of stream and its fairly flat terrain nature could also influence the metabolic activities leading to DO depletion in the mid- section of the stream.

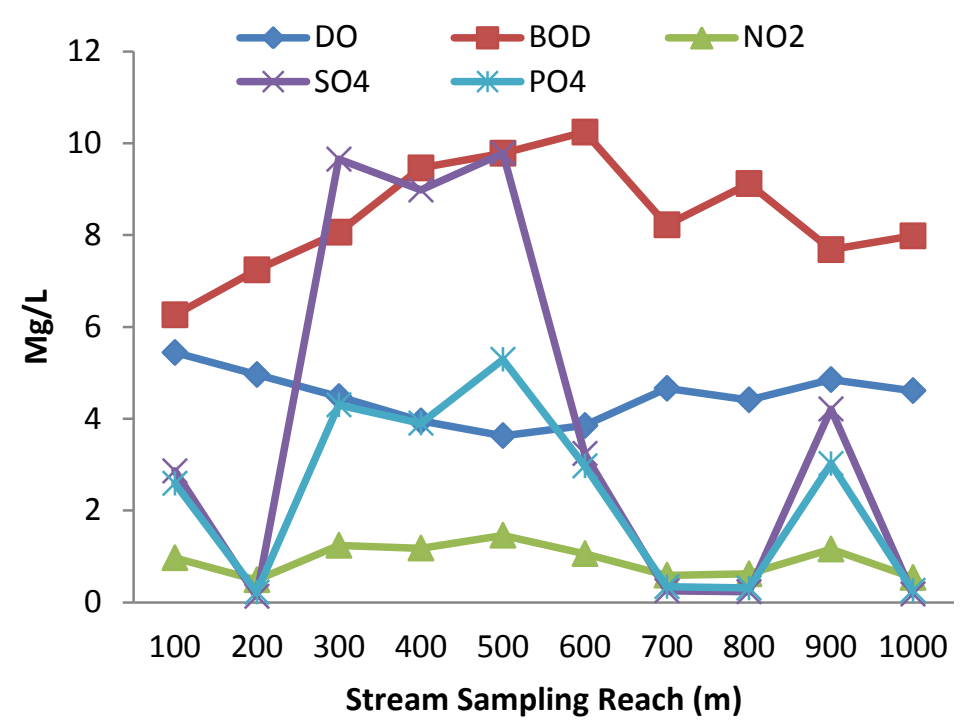

Fig 2: Graph Showing the Trends of Parameters Concentration of the Sokori Stream Along its Water Stretch. SOURCE: FIELD SURVEY, 2014.

Figure 3 show the mean concentration of nutrients along the Sokori stream. It is obvious that sulphate has the highest concentration $(3.60 \mathrm{Mg} / \mathrm{l})$, followed by phosphate $(2.13 \mathrm{Mg} / \mathrm{l})$ then nitrate $(0.89 \mathrm{Mg} / \mathrm{l})$. This is as a result of high rate of fossil fuel combustion and eventual deposition through precipitation and run-off.

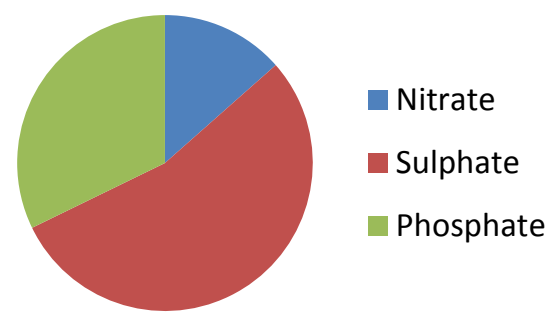

Fig 3: Graph Showing the Mean Concentration of Nutrients (Nitrates, Sulphates and Phosphates) in Sokori Stream.

SOURCE: FIELD SURVEY, 2014. 
Major Sources of Nutrients in Sokori Stream: The Figure 1 above also shows the main sources of nutrients (nitrate, phosphates and sulphates) in Sokori stream. There is an indication that human settlements, markets, roads, vegetation etc. which are major point and non-point sources of nutrients in Sokori Stream.

Conclusion: From this study, a high concentration of nutrients were discovered at the middle section of the stream and it is evident that surrounding households were a major contributor to the nutrients found in Sokori Stream. The nutrients-containing salt, were produced at a high rate and at a consistent level usually every day. Sulphate had the highest relative concentration levels compared to other nutrients (that is, phosphates and nitrates) which indicate that it was produced in high amount and at a constant level. However, the nutrient concentrations in the stream were below the acceptable limit set by the World Health Organization, and there was no evidence of accumulation of nutrient leading to eutrophication risk.

\section{REFERENCES}

Capone D.G. and Kiene R.P. "Comparison of microbial dynamics in marine and freshwater sediments: Contrasts in anaerobic carbon catabolism". Limnology and Oceanography. No. 33(1988): 725-749.

Cook R.B. and Kelly C.A. "Sulphur cycling and - uxes in temperate dimictic lakes". R.W. Howarth, J.W.B. 8,9 Stewart and M.V. Ivanov (Eds). Sulphur Cycling on the Continents. John Wiley, Washington (1992): 145-188.
Gatseva P, Argirova MD "High nitrate levels in drinking water may be a risk factor for thyroid dysfunction in children and pregnant women living in rural Bulgarian areas". International Journal of Hygiene and Environmental Health, 211, no.5-6(2008b): 555-559.

Howarth R. "Nutrient limitation of net plenary production in manne ecosystems" Annual. Reverse. Ecology. Systems. 19(1988): 89-110.

Mallin, M.A., V.L. Johnson, S.H. Ensign and T.A. MacPherson. "Factors contributing to hypoxia in rivers, lakes and streams". Limnology and Oceanography 51(1988): 690-701.

Paul JH. "Uptake of organlc nitrogen". In: Carpenter EJ, Capone DG (eds) Nitrogen in the marine environment. New York: Academic Press, (1983):275-308.

WHO. "Health hazards from nitrate in drinkingwater". Report on a WHO meeting, Copenhagen, 5-9 March 1984. Copenhagen, WHO Regional Office for Europe Environmental Health Series No. 1(1985b). 